\title{
PHYSIOLOGICAL FEATURES OF RED CURRANT VARIETIES AND SELECTED SEEDLING ADAPTATION TO DROUGHT AND HIGH TEMPERATURE
}

\section{O.V. PANFILOVA, O.D. GOLYAEVA}

All-Russian Research Institute of Breeding Fruit Crops, Federal Agency of Scientific Organizations, d. Zhilina, Orel Region, Orel Province, 302530 Russia, e-mail info@vniispk.ru, olga_280682@mail.ru (corresponding author) ORCID:

Panfilova O.V. orcid.org/0000-0003-4156-6919

The authors declare no conflict of interests

Received May 25, 2016

\author{
Golyaeva O.D. orcid.org/0000-0003-1106-634X
}

\begin{abstract}
Adaptation to weather conditions is an important feature of cultivars. To assess plant adaptability, we applied a physiological test of Ribesia (Berl.) Jancz. leaf resistance to abiotic factors during vegetation. The effect of high temperatures and drought on red currant plant photosynthetic apparatus and water regime was studied in 2011-2013 in the Central-Chernozem region (Orel region). Five varieties and three selected seedling genotypes of different eco-geographic and genetic origin were used including the derivatives of Ribes petraeum Wulf., $R$. vulgare Lam. and $R$. multiflorum Kit. (of these, six genotypes were originated in VNIISPK). Leaves of red currant plants are known to have a mesomorphic structure characteristic of Ribesia (Berl.) Jancz. subgenus. In this paper, it was shown that the morphological characteristics of leaves (i.e., shape, venation) are determined by the biological features of varieties while growing conditions alter the anatomical structure. We found a positive correlation between the leaf area and hydrothermal coefficient $(r=+0.99)$ and negative correlation between the leaf area and environment temperature $(r=-0.97)$. An increase in leaf thickness, the expansion of spongy parenchyma cells, a decrease in chlorophylls (both Chla and Chla + Chlb), as well as elevated carotenoid level are the response to stress factors during vegetation. The ratio coefficient of chlorophyll sum to carotenoids is considered as one of the adaptation indices. High coefficients were revealed in Hollandische Rote variety (5.14) and 1426-21-80 (5.51). Correlations between the chlorophyll sum and water loss $(r=-1.00)$ as well as chlorophyll sum and fraction of available water $(r=+0.98)$ were ascertained. The pigment content, fractional composition of water and water holding capacity of leaves are interconnected with the water shortage. The positive correlation of air temperature and water deficit $(r=+0.84)$ has been noted. The total water content in red currant leaves depends on the shoot growth, leaf age, variety, meteorological conditions and is not the main indicator of resistance to high temperatures and drought. Ratios of bound and free water and water holding capacity of leaves vary depending on meteorological conditions and water availability. In 2012 the weather conditions were unfavorable, and in all red currant genotypes the increase of the coefficient of bound water to available water as well as drop in water loss were observed. According to the parameters of water regime, Hollandische Rote variety and 1426-21-80 displayed high adaptability. The laboratory diagnostic methods were confirmed by the field data of genotype resistance under high temperature and moisture deficiency. Thus, the physiological express tests are suitable for estimation of red currant plant adaptability to environmental factors in the course of breeding. A comprehensive assessment showed diverse ecological plasticity in the plants with different Ribesia (Berl.) Jancz. subgenus species in the pedigree. The derivatives of Ribes petraeum Wulf. (Hollandische Rote) and $R$. multiflorum Kit. (1426-21-80) showed the highest tolerance to drought conditions during the vegetation season in the Central Chernozem region. The varieties and seedlings derived from $R$. vulgare Lam. had low drought resistance.
\end{abstract}

Keywords: red currant, drought resistance, leaf, mesostrurture, pigments, fractional structure of water, water holding ability

Red currant is one of valuable berry crops having high yield, early maturity, and good food qualities of berries. A total of 50 to $80 \%$ of its yield losses are accounted for the negative effect of natural climatic factors. The most important of these is an increase in the instability and stress of weather conditions $[1,2]$. In the Central Black Earth Region, such stressors include drought caused 
by high temperatures. An increase in temperature causes morpho-anatomical, physiological and biochemical alterations that affect the growth and development of plants and can lead to a reduction in commercial yield [3-5]. Studying the morphological features, the structure of the photosynthetic apparatus and water exchange of plants with regard to the growth area are necessary for solving fundamental and applied problems of the biology of red currant. Currently, physiological and biochemical express methods are appreciated in estimation of plant resistance to adverse weather and climatic factors that makes it possible to significantly optimize breeding, to minimize yield losses and to create genotypes resistant to the destructive effect of climatic anomalies [6].

Plants have various mechanisms of adaptation to stressors [8-10]. The xenomorphic leaf structure, alterations in the pigment complex and water balance are important diagnostic features of drought resistance [11-13]. Thus, at increasing drought, palisade mesophyll cells of black currant Ribes americanum Mill. increase in size, and the amout of retained water in cells also increases. In some red currant varieties derived from $R$. vulgare Lam. species (Gollandskaya rozovaya, Natali krasnaya), the content of the total a and b chlorophyll and photosynthesis decrese [14-16]. A similar regularity is characteristic of strawberry, grapes, chestnut, tea plants (Camellia sinensis) and olive trees (Olea evropaea L.) under increasing temperature [17-20]. In fruit, vegetable and leguminous crops, a decrease in water retaining during the light day, an increase in transpiration and alterations in the ratio of water forms in various plant parts were observed [21-23]. Adaptation of berry crops including red currant to stressors during vegetation period is poorly studied and requires a more detailed investigation.

This paper is the first reporting application of physiological methods to detect resistance of red currant leaf photosynthetic apparatus to adverse factors during vegetation.

The aim of our study was to investigate water regime, photosynthesis and productivity in various species of Ribesia (Berl.) Jancz. subgenus, and also to identify varieties and breeding forms resistant to drought and elevated temperature.

Techniques. The observations were carried out in 2011-2013 at the primary nursery for red currant (All-Russian Research Institute for Breeding Fruit Crops, ARRIBFC). Aridness during the vegetation periods was assessed by a hydrothermal coefficient (HTC). Eight red currant genotypes were studied, including 6 cultivars of ARRIBFC (Dana, Niva, Roza, 1518-37-14, 1426-21-80, 143229-98) and 2 foreign ones (Jonkheer Van Tets, Hollandische Rote). The samples had different genetic, ecological and geographical origins and were derivatives of the Ribes petraeum Wulf. (Hollandische Rote, 1518-37-14), R. vulgare Lam. (Jonkheer Van Tets, Niva, Roza), and R. multiflorum Kit. (Dana, 1426-21-80, 1432-29-98) species.

Morpho-anatomical structure of leaves was assessed by studying their mesostructure [24] using a microscope Eclipse 50i (Nikon, Japan, ×400). The pigment content was determined in $80 \%$ acetone extract [25] using a Smart Spec ${ }^{\mathrm{TM}}$ Plus (Bio-Rad, USA) spectrophotometer. The water regime parameters were determined according to the developed techniques [11, 26, 27].

Dispersion, correlation and regression analyses were carried out at $95 \%$ significance level [28] using the Microsoft Excel 2010 software package.

Results. The weather conditions varied strongly over the years of studies. From May to June of 2011, there was a combination of high water supply and elevated temperatures $\left(\mathrm{HTC}=0.93 ; 1.12 ; 2.10 ;+30.0 \ldots+31.5{ }^{\circ} \mathrm{C}\right) .2012$ was the most arid year $\left(\mathrm{HTC}=0.20 ; 0.82 ; 0.40 ;+31.2 \ldots+32.2{ }^{\circ} \mathrm{C}\right)$. The vegetation period of 2013 was intermediate according to hydrothermal conditions $\left(\mathrm{HTC}=0.72 ; 0.89 ; 0.68 ;+28.6 \ldots+31.5^{\circ} \mathrm{C}\right)$. 
Morphological variability and ecological plasticity are characteristic of Ribesia (Berl.) Jancz. subspecies. Red currant belongs to mesophytes. All its varieties and forms are derived from wild species (Ribes petraeum Wulf., R. rubrum L., $R$. vulgare Lam., $R$. multiflorum Kit.), growing in the intermediate zone of the Northern hemisphere in the regions with high soil humidity and average air temperature during vegetation. Europe is believed to be the origin of the $R$. vulgare Lam., while $R$. petraeum Wulf. is distributed in mountaneous regions of Europe and North Africa. The origin of $R$. multiflorum Kit. is Southern Europe $[29,30]$. Study of the assimilation apparatus in varieties and selection forms of various red current species in the Russian Central Region is of special interest because specific climatic conditions significantly affect the formation and functions of leaf apparatus.

Studies have shown that some morphological features (shape, veining) of red currant leaves depended on the biological features of the variety, and the anatomical structure was affected by growth conditions. In the periods with insignificant water supply, the leaf area reduced in all studied samples compared to the optimal conditions: it was $17.64 \mathrm{~cm}^{2}$ on the average in $2011,13.95 \mathrm{~cm}^{2}$ in 2012, and $14.37 \mathrm{~cm}^{2}$ in 2013. Thereby, maximum leaf area was noted in 2011 to 2013 in 1426-21-80 sample, the derivative of $R$. multiflorum Kit. A positive relationship was between the leaf area and HTC $(r=+0.99)$ and a negative one was between the leaf area and the temperature $(r=-0.97)$.

The leaves of red currant plants had a mesomorphous structure characteristic of Ribesia (Berl.) Jancz. subspecies. The spongy parenchyma was predominant over the palisade one and the epidermal cells appeared to be large enough, being larger on the upper side of the leaf than on the lower one. High temperature and drought differently affected the sizes of the adaxial epidermal cells and the mesostructure of a leaf. In 2012 and 2013 from May to July, the main cells of the adaxial epidermis in the Hollandische Rote variety ( $R$. petraeum Wulf.) and the selection form 1426-21-80 (R. multiflorum Kit.) affected by high temperatures $\left(+31.2 \ldots+28.6{ }^{\circ} \mathrm{C}\right.$ in May, and $+32.2 \ldots+31.5{ }^{\circ} \mathrm{C}$ in July) somewhat elongated, which was associated with reduced cell turgor. We have noted cell shrinkage in the tangential direction (parallel to the palisade surface) in the remaining samples (Fig. 1).

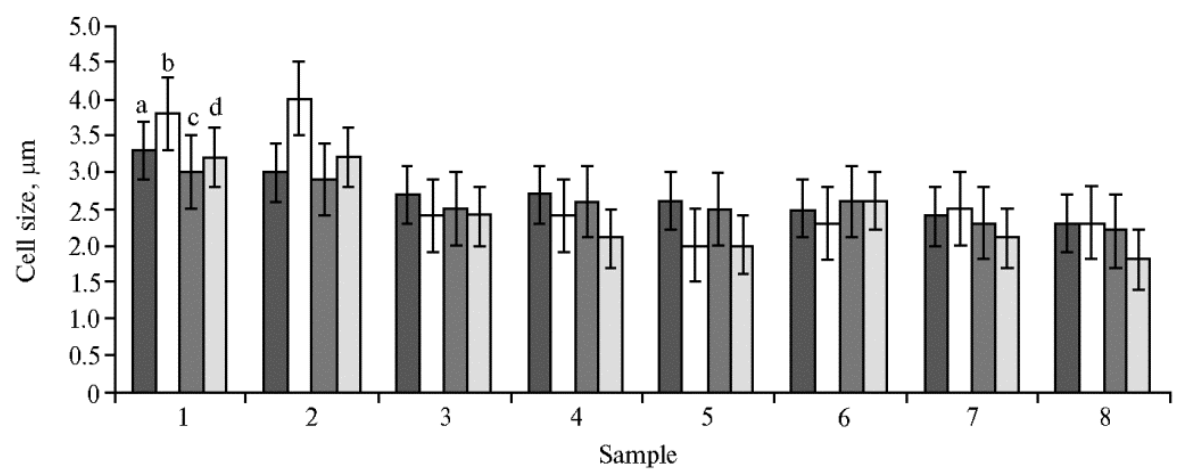

Fig. 1. Cell size in the leaf adaxial epidermis of red currant varieties and forms in May (a) and in July (b) 2012 and also in May (c) and July (d) 2013: 1 - Hollandische Rote, 2 - 1426-21-80, 3 - Dana, 4 - 1432-29-98, 5 - Niva, 6 - 1518-37-14, 7 - Jonkheer Van Tets, 8 - Roza (All-Russian Research Institute for Breeding Fruit Crops, Orel Province, Zhilina village).

The elevated temperature and drought in 2012 and 2013 has led to the growth of parenchymal cells and an increase in leaf thickness (Table 1). The growth of mesophyll cells occurred mainly due to the increase in the aircontained elements of spongy parenchyma which facilitated gas exchange be- 
tween a leaf and environment. Cell growth in spongy parenchyma and an increase in leaf thickness compared to 2011 were found almost in all of the samples, except Niva variety, especially in Hollandische Rote plants and 1426-2180. These changes should be viewed as a manifestation of a high adaptability of the anatomical leaf structure to stressors during the vegetation period.

1. Leaf mesostructure in the red currant varieties and forms as depended on year conditions (All-Russian Research Institute for Breeding Fruit Crops, Orel Province, Zhilina village)

\begin{tabular}{|c|c|c|c|c|c|c|c|c|c|}
\hline \multirow{3}{*}{ Sample (B) } & \multicolumn{9}{|c|}{ Year (A) } \\
\hline & \multicolumn{3}{|c|}{2011} & \multicolumn{3}{|c|}{2012} & \multicolumn{3}{|c|}{2013} \\
\hline & PP & SP & TLT & PP & SP & TLT & PP & SP & TLT \\
\hline Hollandische Rote & 10.29 & 13.62 & 26.94 & 12.00 & 20.00 & 37.30 & 9.75 & 15.80 & - \\
\hline Niva & 9.56 & 15.24 & 27.70 & 11.25 & 18.45 & 35.35 & 9.55 & 16.95 & 31.40 \\
\hline Dana & 9.28 & 12.65 & 24.63 & 10.15 & 15.35 & 29.60 & 10.35 & 15.30 & 29.10 \\
\hline Jonkheer Van Tets & 8.10 & 12.00 & 22.70 & 10.05 & 16.30 & 29.92 & 9.10 & 14.85 & 27.70 \\
\hline Roza & 7.90 & 12.35 & 23.25 & 11.65 & 17.55 & 33.65 & 10.15 & 15.10 & 29.10 \\
\hline Hollandische Rote & 7.70 & 14.68 & 25.38 & 9.15 & 18.15 & 30.80 & 8.55 & 16.90 & 29.15 \\
\hline Niva & 7.30 & 10.10 & 20.33 & 10.50 & 15.90 & 30.05 & 9.00 & 12.30 & 24.80 \\
\hline Dana & 6.80 & 11.23 & 20.53 & 7.95 & 13.85 & 25.60 & 8.10 & 13.80 & 25.10 \\
\hline
\end{tabular}

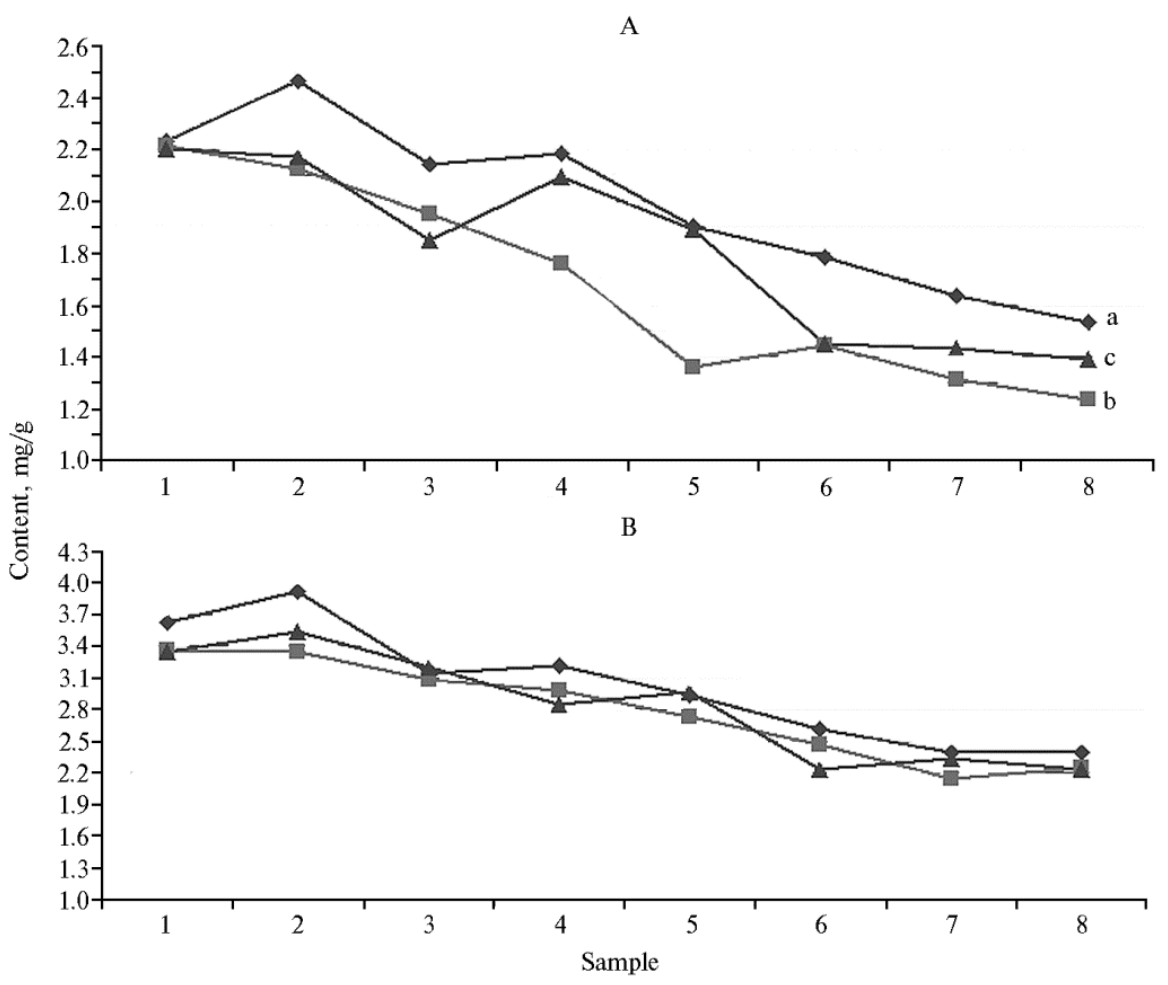

Fig. 2. Chlorophyll a (A) and chlorophylls $a+b$ (B) content during vegetation in 2011 (a), 2012 (b) and 2013 (c) in the leaves of red currant varieties and forms: 1 - Hollandische Rote, $2-1426-21$ 80, 3 - Dana, 4 - 1432-29-98, 5 - Niva, 6 - 1518-37-14, 7 - Jonkheer Van Tets, 8 - Roza (All-Russian Research Institute for Breeding Fruit Crops, Orel Province, Zhilina village). A: a $\mathrm{LSD}_{05}=0.31 ; \mathrm{b}-\mathrm{LSD}_{05}=0.26 ; \mathrm{c}-\mathrm{LSD}_{05}=0.29$. B $\mathrm{a}-\mathrm{LSD}_{05}=0.61 ; \mathrm{b}-\mathrm{LSD}_{05}=0.53$; $\mathrm{c}-\mathrm{LSD}_{05}=0.58$.

The weather conditions during vegetation have significantly affected assimilation apparatus. In the arid 2012, a reduction in chlorophyll a and $\mathrm{a}+\mathrm{b}$ chlorophylls (1.23-2.21 and 2.15-3.36 mg/g, respectively) was noted in the leaves of all red currant cultivars compared to 2011 (1.53-2.46 and $2.40-3.92 \mathrm{mg} / \mathrm{g}$ ) 
(Fig. 2). It should be noted that a more drastic decrease in the pigment amount in 2012 occurred in all derivatives of the $R$. vulgare Lam. Species; the minimal one was in $R$. petraeum Wulf. and $R$. multiflorum Kit. plants. Insignificant drought relief in 2013 facilitated a small increase in the pigment content.

Drought together with high temperatures stimulated the formation of carotenoids in all of the samples of Ribesia (Berl.) Jancz. subgenus studied, which is consistent with findings about the protective function of this pigment group at stress [21, 31, 32]. We have found a positive correlation between the carotenoid content and temperature $(r=+0.77)$. Some scholars in order to assess stressor resistance suggest using the coefficient of the total chlorophyll to carotenoid ratio [31, 33, 34]. Under stress conditions of 2012, the Hollandische Rote variety and 1426-21-80 plants with the coefficient of 5.14 and 5.51, respectively, were distinct in this parameter, which may indicate their resistance to drought and high summer temperatures. The hydrothermal regime affects productivity by affecting the functional state of the plants which was confirmed by high correlations between the chlorophyll a level and yield $(r=+0.85)$, and total chlorophylls and yield $(r=+0.78)$

The pair correlation coefficients between total chlorophylls and water loss $(r=-1.00)$, and total chlorophylls and free water amount $(r=+0.98)$ confirmed the dependence of the pigment content on water regime parameters. These parameters (pigment content, water fractions, water-retaining leaf capacity) were associated with the development of water deficiency which depended on air temperature $(r=+0.84)$. The relationship between the water regime parameters and the meteorological features of the vegetation period was described using multiple regression coefficients (Table 2).

2. Correlation between physiological parameters of the red currant samples and the meteorological factors (All-Russian Research Institute for Breeding Fruit Crops, Orel Province, Zhilina village)

\begin{tabular}{lc}
\hline \multicolumn{1}{c|}{ Parameter } & Regression coefficient \\
\hline Water content & $0.90 \cdot \mathrm{F} ; \mathrm{r}=0.22$ \\
Free water fraction & $0.84 \cdot \mathrm{F} ; \mathrm{r}=0.33$ \\
Water loss & $-0.88 \cdot \mathrm{F} ; \mathrm{r}=0.30$ \\
\hline N o t e. F - hydrothermal coefficient, $\mathrm{r}-$ standard experiment error. & \\
\hline
\end{tabular}

It should be noted that the total water content in red currant leaves is not the main parameter of plant resistance to elevated temperatures and drought, because it depends on a number of factors (sprout growth, leaf age, berry formation, weather conditions and variety) [35] (Fig. 3).

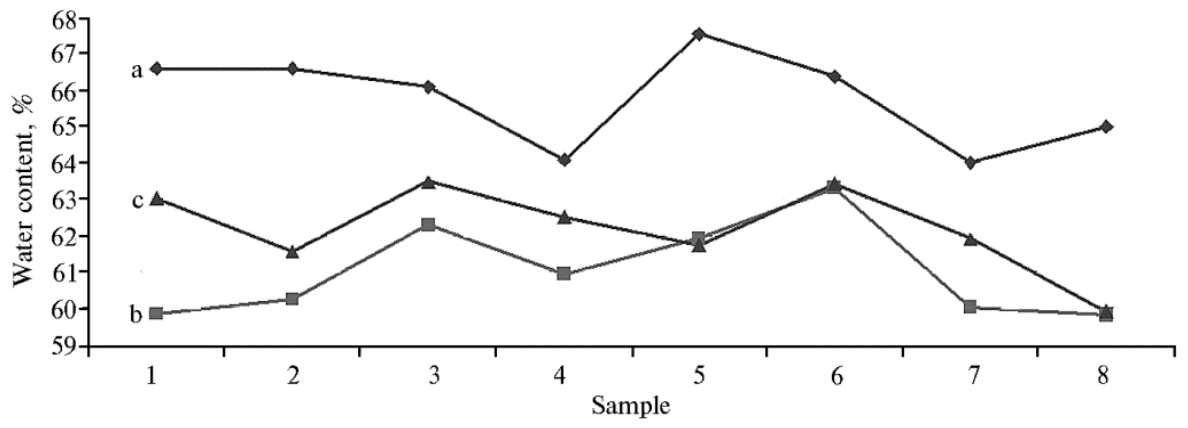

Fig. 3. Water content in leaves during vegetation in 2011 (a), 2012 (b) and 2013 (c) in the red currant varieties and forms: 1 - Hollandische Rote, 2 - 1426-21-80, 3 - Dana, 4 - 1432-29-98, 5 Niva, 6 - 1518-37-14, 7 - Jonkheer Van Tets, 8 - Roza (All-Russian Research Institute for Breeding Fruit Crops, Orel Province, Zhilina village). $\mathrm{LSD}_{05}$ : a $-4,38, \mathrm{~b}-3,74, \mathrm{c}-3,98$

The most labile parameters, depending on meteorological conditions and 
water supply, are the ratios of the bound and free water and the water retaining capacity of leaves $[11,36,37]$. We assessed the water retaining capacity based on water loss. Among the studied traits in the stress period, significant differences were associated with variety and specific features. In 2012 with unfavorable HTC compared to 2011, an increase in the ratio of bound and free water and a decrease in leaf water loss were observed in all the samples. In 2013, this ratio was higher than that in 2011, but lower compared to the parameter of 2012 (Table 3). The highest values of the coefficient and minimal water loss were noted in the Hollandische Rote plants and the 1426-21-80 form; this gives grounds to believe that genotypes of these $R$. petraeum Wulf. and $R$. multiflorum Kit. samples manifest a higher adaptability to high temperatures under soil moisture deficiency.

3. Main parameters of water regime in the red currant varieties and forms aas depended on year conditions (All-Russian Research Institute for Breeding Fruit Crops, Orel Province, Zhilina village)

\begin{tabular}{|c|c|c|c|c|c|c|c|c|}
\hline \multirow{3}{*}{ Sample (B) } & \multicolumn{8}{|c|}{ Year (A) } \\
\hline & \multicolumn{2}{|c|}{2011} & \multicolumn{2}{|c|}{2012} & \multicolumn{2}{|c|}{2013} & \multicolumn{2}{|c|}{ average } \\
\hline & $\mathrm{BW} / \mathrm{FW}$ & WL, \% & $\mathrm{BW} / \mathrm{FW}$ & WL, \% & $\mathrm{BW} / \mathrm{FW}$ & WL, \% & $\mathrm{BW} / \mathrm{FW}$ & WL, \% \\
\hline Hollandische Rote & 1.33 & 35.82 & 2.09 & 20.36 & 2.03 & 21.11 & 1.82 & 25.76 \\
\hline $1426-21-80$ & 1.31 & 36.16 & 2.41 & 20.62 & 2.09 & 19.37 & 1.94 & 25.38 \\
\hline $1432-29-98$ & 1.12 & 30.17 & 1.42 & 25.01 & 1.20 & 26.98 & 1.25 & 27.39 \\
\hline Jonkheer Van Tets & 1.01 & 38.10 & 1.31 & 21.85 & 1.04 & 27.40 & 1.12 & 29.12 \\
\hline $1518-37-14$ & 0.96 & 40.91 & 1.06 & 27.62 & 1.08 & 26.66 & 1.03 & 31.73 \\
\hline Niva & 0.82 & 42.56 & 1.71 & 24.84 & 1.50 & 25.58 & 1.34 & 30.99 \\
\hline Dana & 0.70 & 40.97 & 1.76 & 25.51 & 1.66 & 25.44 & 1.37 & 30.64 \\
\hline Roza & 0.63 & 39.75 & 0.98 & 26.82 & 0.87 & 27.85 & 0.83 & 31.47 \\
\hline $\mathrm{LSD}_{05}$ & 0.08 & 2.06 & 0.11 & 3.03 & 0.14 & 1.86 & & \\
\hline
\end{tabular}

Note. BW/FW - coefficient of the bound to free water ratio, WL - water loss over $24 \mathrm{~h}, \%$. LSD $_{05}$ for BW/FW: $\mathrm{A}-2.18$; $\mathrm{B}-4.59 ; \mathrm{AB}-7.95 . \mathrm{LSD}_{05}$ for $\mathrm{WL}: \mathrm{A}-0.13$; $\mathrm{B}-0.21 ; \mathrm{AB}-0.37$.

Therefore, prospects of physiological methods in assessment of resistance to unfavorable weather factors have been shown in the members of Ribesia (Berl.) Jancz. subgenus. The obtained results are fully consistent with data about field resistance of red currant varieties and forms under elevated temperature and moisture deficiency. This allows using the said methods for express diagnostics that significantly intensify breeding for adaptability. The complex physiological assessment has shown that the derivatives of various species of Ribesia (Berl.) Jancz. subgenus have different ecological plasticity which is explained by differences in their genetic and ecological and geographic origins. The highest resistance to drought during vegetation in the Central Black Soil Region was manifested in the derivatives of Ribes petraeum Wulf. (Hollandische Rote) and $R$. multiflorum Kit. (1426-21-80) species. Low drought resistance was noted in the varieties and forms of $R$. vulgare Lam.

\section{REFEREN CES}

1. Vollenweider P., Günthardt-Goerg M.S. Diagnosis of abiotic and biotic stress factors using the visible symptoms in foliage. Environ. Pollut., 2005, 137: 455-465 (doi: 10.1016/j.envpol.2005.01.032).

2. Christensen J.H., Christensen O.B. A summary of the PRUDENCE model projections of changes in European climate by the end of this century. Climatic Change, 2007, 81: 730 (doi: 10.1007/s10584-006-9210-7).

3. Ki m K., Portis A.R. Temperature dependence of photosynthesis in Arabidopsis plants with modifications in Rubisco actives and membrane fluidity. Plant Cell Physiol., 2005, 46: 522-530 (doi: 10.1093/pcp/pci052).

4. B e ck E.H., Fettig S., Knake C., Hartig K., B hat tarai T. Specific and unspecific responses of plants to cold and drought stress. J. Biosciences, 2007, 32: 501-510 (doi: 10.1007/s12038-007-0049-5).

5. Has a nuzzam an M., Nahar K., Fujit a M. Extreme temperature responses, oxidative stress and antioxidant defense in plants. In: Abiotic stress - plant response and applications in agriculture. K. Vahadati, C. Leslie (eds.). INTECH, 2013 (doi: 10.5772/54833). 
6. N e e ru K., Ka lp na B., Kad a mbot H.M.S., Ha rs h N. Food crops face rising temperatures: An overview of responses, adaptive mechanisms, and approaches to improve heat tolerance. Cogent Food \& Agriculture, 2016, 2(1): 271-313 (doi: 10.1080/23311932.2015.1134380).

7. Wise R.R., Olson A.J., Schrader S.M., Sharkey T.D. Electron transport is the functional limitation of photosynthesis in field-grown Pima cotton plants at high temperature. Plant Cell Environ., 2004, 27(6): 717-724 (doi: 10.1111/j.1365-3040.2004.01171.x).

8. Wahid A., Gelani S., Ashraf M., Foolad M. Heat tolerance in plants: An overview. Environ. Exp. Bot., 2007, 61: 199-223 (doi: 10.1016/j.envexpbot.2007.05.011).

9. B a celar E.A., S a ntos D.L., Mout inho-Pereira J.M., Gonçalves B.C., Ferrei r H.F., C orre i a C.M. Immediate responses and adaptative strategies of three olive cultivars under contrasting water availability regimes: Changes on structure and chemical composition of foliage and oxidative damage. Plant Science, 2005, 170(3): 596-605 (doi: 10.1016/j.plantsci.2005.10.014).

10. Ko in i M.A., Alve y L., Allen T., Tille y C.A., Harberd N.P., White 1 a m G.C., Franklin K.A. High temperature-mediated adaptations in plant architecture require the bHLH transcription factor PIF4. Curr. Biol., 2009, 19: 408-413 (doi: 10.1016/j.cub.2009.01.046).

11. Kushnirenko M.D. Metody izucheniya vodnogo obmena $i$ zasukhoustoichivosti plodovykh rastenii [Methods of studing water exchange and drought resistance in fruit crops]. Kishinev, 1970 (in Russ.).

12. Davlatov S.Kh., A s hurov A.A., B a i kova E.V. Vestnik Tomskogo gosudarstvennogo universiteta, 2009, 323: 348-350 (in Russ.).

13. Skhalyakho T.V., Nen'k o N.I, K ise leva G.K. Plodovodstvo i vinogradarstvo Yuga Rossii, 2012, 17: 69-78 (in Russ.).

14. R e z a nova T.A., S o r o k o p ud ov V.N. Materialy Mezhdunarodnoi nauchno-prakticheskoi konferentsii «Biologicheski aktivnye soedineniya prirodnogo proiskhozhdeniya: fitoterapiya, farmatsevticheskii marketing, farmatsevticheskaya tekhnologiya, botanika» [Proc. Int. Conf. «Natural bioactive compounds: phytotherapy, pharm market, pharmaceutical thechnologies, and botany»]. Belgorod, 2008: 133-135 (in Russ.).

15. R e z a n ov a T.A. Morfo-anatomicheskie i ekologicheskie osobennosti Ribes americanum Mill. pri introduktsii na yuge Srednerusskoi vozvyshennosti. Avtoreferat kandidatskoi dissertatsii [Morphological, anatomical and ecological features of Ribes americanum Mill. introduced in the south of Central Russian Upland. PhD Thesis]. Saratov, 2010 (in Russ.).

16. Filat ova L.A., Pachina T.D. Vestnik Permskogo universiteta, 2007, 5(10): 28-30 (in Russ.).

17. D u Y.Y., S h i n S., W a ng K.R., Lu J.L., Li a ng Y.R. Effect of temperature on the expression of genes related to the accumulation of chlorophylls and carotenoids in albino tea. The Journal of Horticultural Science and Biotechnology, 2009, 84(3): 365-369 (doi: 10.1080/14620316.2009.11512533).

18. B a c e 1 a r E.A. Ecophysiological responses of olive (Olea europaea L.) to restricted water availability: Limitations, damages and drought resistance mechanisms. Universidade De Trás-Os-Montes E Alto Douro, Vila Real, 2006.

19. Zhang B.C., Laranjo J.G., Correia C.M., Moutinho-Pereira J.M., Carvalho Goncalves B.M., B a celar E.A., Peixoto F.P., Response V.G. Response, tolerance and adaptation to abiotic stress of olive, grapevine and chestnut in the Mediterranean region: role of abscisic acid, nitric oxide and microRNAs. In: Plants and environment. K.N. Hemanth (ed.). INTECH, 2011: 179-206 (doi: 10.5772/24719).

20. Khvostov D.S. Mekhanizmy adaptatsii $i$ zasukhoustoichivost' sortov $i$ gibridov zemlyaniki. Avtoreferat kandidatskoi dissertatsii [Mechanisms of adaptation and drought redidtance in strawberry plant of different varieties and hybrids. PhD Thesis]. Krasnodar, 2000 (in Russ.).

21. K is il e va N.S. Materialy Mezhdunarodnoi nauchno-prakticheskoi konferentsii «Adaptivnyi potentsial $i$ kachestvo produktsii sortov $i$ sorto-podvoinykh kombinatsii plodovykh kul'tur» [Proc. Int. Conf. «Adaptiveness and quality parameters in fruit crop cultivrars and rootstock combinations»]. Orel, 2012: 115-122 (in Russ.).

22. Mazorra L.M., Nunez M., Echerarria E., Coll F., Sánchez-Blanco M.J. Influence of brassinosteriods and antioxidant enzymes activity in tomato under different temperatures. Biologia Plantarum, 2002, 45: 593-596 (doi: 10.1023/A:1022390917656).

23. O $\mathrm{m}$ a e H., $\mathrm{Ku}$ ma r A., $\mathrm{S}$ ho no $\mathrm{M}$. Adaptation to high temperature and water deficit in the common bean (Phaseolus vulgaris L.) during the reproductive period. Journal of Botany, 2012, (2012): Article ID 803413 (doi: 10.1155/2012/803413).

24. Mok ro nos ov A.T., B o r z e n k va R.A. Trudy po prikladnoi botanike, genetike $i$ selektsii, 1978, 61(3): 119-128 (in Russ.).

25. Gavrile nko V.F., Ladygina M.E., Khandobina L.M. Bol'shoi praktikum po fiziologii rastenii. Fotosintez. Dykhanie [Plant Physiology: phosynthesis and respiration (pratical works)]. Moscow, 1975 (in Russ.).

26. Baslavskaya S.S., Trubetskova O.M. Praktikum po fiziologii rastenii [Plant physiology]. 
Moscow, 1964 (in Russ.).

27. Programma $i$ metodika sortoizucheniya plodovykh, yagodnykh $i$ orekhoplodnykh kul'tur /Pod redaktsiei E.N. Sedova, T.P. Ogol'tsovoi [Program and methods of studying varieties of fruit, berry and nut crops. E.N. Sedov, T.P. Ogol'tsova (eds.)]. Orel, 1999 (in Russ.).

28. D o s p e k hov B.A. Metodika polevogo opyta s osnovami statisticheskoi obrabotki rezul'tatov issledovaniya [Methods of field trials]. Moscow, 1985 (in Russ.).

29. F e d o r o v s k i i V.D. Ribes spicatum Robson. - smorodina kolosistaya (sistematika, geografiya, izmenchivost', introduktsiya) [Ribes spicatum Robson. - red currant (systematics, geography, variability, and introduction]. Kiev, 2001 (in Russ.).

30. S o r o k o pud ov V.N., S olov'e va A.E., S m i r nov A.S. Krasnaya smorodina v lesostepi Priob'ya [Red currant in the steppe-forest area of Ob river basine]. Novosibirsk, 2005 (in Russ.).

31. Krivoruchko V.P. Ekologo-biologicheskie osnovy povysheniya produktivnosti yablonevykh sadov severnogo Kyrgyzstana. Doktorskaya dissertatsiya [Ecobiological aspects of fruit garden yielding in the North Kyrgyzstan. DSc Thesis]. Bishkek, 1998 (in Russ.).

32. K h v o st o v D.S., K i r t b a y E.K. Sadovodstvo $i$ vinogradarstvo, 1999, 4: $16-17$ (in Russ.).

33. K i s e l e va N.S. Estimation of adaptability in different pear genotypes on morpho-anatomical and physiological state of leaves. Sel'skokhozyaistvennaya biologiya [Agricultural Biology], 2009, 3: 34-38 (in Russ.).

34. N e n'k o N.I., I l'i n a I.A., S k ha ly a k ho T.V. Materialy Mezhdunarodnoi nauchnoi konferentsii «Vysokotochnye tekhnologii proizvodstva, khraneniya i pererabotki vinograda» [Proc. Int. Conf. «Current technologies of grape growing, storage and processing»]. Krasnodar, 2010: 50-59 (in Russ.).

35. Panfilova O.V., Ozherel'eva Z.E., Goly a e va O.D. Sortovivchennya ta okhorona prav na sorti roslin, 2014, 1(22): 24-27 (in Russ.).

36. M a chad o S., Pa uls e n G.M. Combined effects of drought and high temperature on water relations of wheat and sorghum. Plant Soil, 2001, 233(2): 179-187 (doi: 10.1023/A:1010346601643).

37. Mironova L.N., De nis ova S.G., Z e in etd inova G.S., Re u t A.A. Vestnik Voronezhskogo gosudarstvennogo universiteta, Seriya: Geografiya. Geoekologiya, 2011, 1: 157-159 (in Russ.). 